\title{
Meteorological conditions, ozone concentration and leaf age affect gas exchange in Psidium guajava 'Paluma'
}

\author{
Juliana Moreno Pina ${ }^{1}$, Sérgio Tadeu Meirelles ${ }^{2}$ and Regina Maria de Moraes ${ }^{3,4}$
}

Received: 24.06.2016; accepted: 9.03.2017

\begin{abstract}
Meteorological conditions, ozone concentration, and leaf age affect gas exchange in Psidium guajava 'Paluma'). This study aimed to investigate the importance of leaf age, meteorological conditions and ozone concentration $\left(\mathrm{O}_{3}\right)$ on gas exchange of Psidium guajava 'Paluma'. Saplings were grown and exposed in standard conditions in the city of São Paulo, in six periods of three months with weekly measurements in young and mature leaves. Gas exchanges were higher in young leaves for almost the entire experiment. Mature leaves showed greater reduction in gas exchange. The multivariate analysis of biotic and abiotic variables indicated that vapor pressure deficit (VPD), $\mathrm{O}_{3}$ concentration and radiation were the main variables associated with gas exchange decrease in young leaves. In mature leaves the influence of VPD is lower, but the temperature importance is higher. Moreover, the opposition between assimilation and $\mathrm{O}_{3}$ is more evident in mature leaves, indicating their greater sensitivity to $\mathrm{O}_{3}$.

Keywords: carbon assimilation, ozone phytotoxicity, stomatal conductance

RESUMO - (Condições meteorológicas, concentração de ozônio e idade da folha afetam as trocas gasosas em Psidium guajava 'Paluma'). Este estudo teve como objetivo investigar a influência da idade da folha, das condições meteorológicas e da concentração do ozônio $\left(\mathrm{O}_{3}\right)$ nas trocas gasosas em Psidium guajava 'Paluma'. Plantas jovens foram cultivadas e expostas de modo padronizado na cidade de São Paulo, SP, em seis períodos de três meses, com medidas semanais em folhas jovens e maduras. As trocas gasosas foram mais altas nas folhas jovens durante quase todo o experimento. As folhas maduras apresentaram maior redução das trocas gasosas. A análise multivariada das variáveis bióticas e abióticas indicou que o déficit de pressão de vapor (DPV), a concentração de $\mathrm{O}_{3}$ e a radiação foram as principais variáveis associadas à redução das trocas gasosas nas folhas jovens. Nas folhas maduras a influencia do DPV é menor, mas a da temperatura é maior. Por outro lado, a oposição entre assimilação e $\mathrm{O}_{3}$ é mais evidente nas folhas maduras, indicando sua maior sensibilidade ao $\mathrm{O}_{3}$. Palavras-chave: assimilação de carbono, condutância estomática, fitotoxicidade do ozônio
\end{abstract}

\section{Introduction}

Ozone $\left(\mathrm{O}_{3}\right)$ is naturally present in different proportions in the various layers of the atmosphere. It acts as a filter absorbing ultraviolet radiation in the stratosphere. In the troposphere, however, its concentration has been increasing due to the reaction between oxides of nitrogen and volatile organic compounds and, currently, $\mathrm{O}_{3}$ is considered one of the most harmful gas pollutants to plant species and vegetation (Vingarzan 2004).

$\mathrm{O}_{3}$ enters the leaf by diffusion through the stomata during the gas exchanges of $\mathrm{CO}_{2}$ and water. It is dissolved in the intercellular space generating byproducts as reactive oxygen species capable of oxidizing lipids and proteins in cell membranes and inactivates enzymes related to various physiological processes (Bray et at. 2000).

Photosynthesis is one of the first targets of $\mathrm{O}_{3}$ byproducts, as they inactivate ribulose-1, 5-bisphosphate carboxylase/oxygenase (Rubisco) and also reduce its synthesis (Heath et al. 2009). With the increase of mesophytic resistance, the electron transport can be compromised and photoinhibition occurs. In addition, the decrease of carboxylation results in an increase of intercellular carbon dioxide concentration and consequent decrease of stomatal conductance. Stomatal closure is considered a

1. Companhia Ambiental de São Paulo, Av. Prof. Frederico Hermann Jr., 345, 05459-900 São Paulo, SP, Brasil

2. Universidade de São Paulo, Instituto de Biociências, Caixa Postal 11461, 05422-970 São Paulo, SP, Brasil

3. Instituto de Botânica, Caixa Postal 68045, CEP 04045-972 São Paulo, SP, Brasil

4. Corresponding author: regmorae@uol.com.br 
mechanism of protection against stress, however it also reduces the entry of the $\mathrm{CO}_{2}$ necessary for the processes of defense and repair of damages. The balance between maintaining carbon gain and reducing $\mathrm{O}_{3}$ entry is critical for the plant to cope with stress (Zhang et al. 2010).

Since stomatal conductance is modulated by a set of meteorological variables, such as temperature, relative air humidity, vapor pressure deficit, among others, this study aimed to determine the relative importance of these variables in gas exchange processes in Psidium guajava 'Paluma', one of the first tropical species identified as sensitive to $\mathrm{O}_{3}$ (Furlan et al. 2007, Pina \& Moraes 2007). The appearance of visible foliar injuries in 'Paluma' was used as a proof of $\mathrm{O}_{3}$ input, seeing that its occurrence was previously studied and associated with ozone (Furlan et al. 2007, Pina \& Moraes 2007). According to De Temmerman et al. (2004), foliar injuries in sensitive species, triggered by ozone, can be used as a bioindicator in risk assessments, indicating the presence of phytotoxic concentrations of this gas. It was also investigated if the interaction between environmental factors and $\mathrm{O}_{3}$ concentration affects the gas exchange of $\mathrm{CO}_{2}$ and $\mathrm{H}_{2} \mathrm{O}$ in leaves of different ages. The hypotheses tested were: 1) environmental factors interfere in plant response to $\mathrm{O}_{3 ;}$ and 2) older leaves are affected more strongly than young leaves.

\section{Materials and methods}

Study site and cultivation conditions - The study was carried out at the Botanical Institute of São Paulo, SP $\left(23^{\circ} 38^{\prime} \mathrm{S}\right.$ and $\left.46^{\circ} 37^{\prime} \mathrm{W}\right)$, which is surrounded by fragments of vegetation in different regeneration stages and avenues with moderate traffic. It has significant concentrations of $\mathrm{O}_{3}$ and low concentrations of other pollutants (Cassimiro et al. 2016).

Saplings of Psidium guajava 'Paluma' about $30 \mathrm{~cm}$ of height, produced by cuttings of herbaceous branches, were transplanted to plastic pots of $3.0 \mathrm{~L}$, using as substratum Pinus bark, fine vermiculite and coconut fiber in the proportion 2:1:1. Plants were irrigated by capillarity and fertilized monthly with $100 \mathrm{ml}$ of water-soluble solution of $\mathrm{N}: \mathrm{P}: \mathrm{K}(10: 10: 10)$.

Six exposures were performed with approximately 80 days: Autumn 2007 (09/04 to 22/06/2007), Spring 2007 (08/10 to 20/12/2007), Summer 2008 (14/01 to 04/04/2008), Autumn 2008 (07/04 to 27/06/2008), Winter 2008 (14/07/2008 to 26/09/2008) and Spring $2008(13 / 10$ to $12 / 12 / 2008)$.
Climate and air quality - Meteorological data was provided by the Meteorological Station of the Institute of Astronomy, Geophysics and Atmospheric Sciences of the University of São Paulo (IAG/USP), located in the site. The concentrations of ozone $\left(\mathrm{O}_{3}\right)$, monoxide and dioxide of nitrogen (NO and $\mathrm{NO}_{2}$ ) were monitored continuously by analyzers (APOA-360CE, HORIBA ${ }^{\circledR}$ ) coupled to a datalogger (APNA-360E HORIBA ${ }^{\circledR}$ ). The mean and maximum daily concentrations of $\mathrm{NO}_{2}$ and $\mathrm{NO}$ were calculated. Hourly data of $\mathrm{O}_{3}$ concentration were used to calculate the cumulative exposure of $\mathrm{O}_{3}$ above the threshold of $80 \mu \mathrm{g} \mathrm{m}^{-3}$ during the light period (CLRTAP 2015).

Visible foliar injury - Foliar injuries were evaluated weekly based on the criteria established in literature and previous studies with 'Paluma' under controlled and field conditions (Furlan et al. 2007, Pina \& Moraes 2007): symptoms do not occur on veins and veinlets, appear as dark-colored stipple (reddish) on the adaxial surface of the leaf and initially reach the old leaves. In 'Paluma', $\mathrm{O}_{3}$-induced injuries are reddish stippling resulting from the formation and accumulation within the vacuole of palisade parenchyma cells of phenolic pigments such as anthocyanin and total tannins (Sandré et al. 2014, Alves et al. 2016).

The percentage of leaf area covered by injuries was estimated in intervals of $1-5 \%$ (class 1 ), $6-25 \%$ (class 2), 26 - 50\% (class 3), 51 - 75\% (class 4) and 76 $100 \%$ (class 5) and then calculated a weighted average of these data, the Leaf Injury Index (LII), according to Furlan et al. (2007). The incidence (number of plants with injuries in relation to the total number of plants) and severity (number of leaves with injuries in relation to the total number of leaves of the plants with injuries) were also calculated. As a reference for the evaluation of foliar injuries, a lot of 'Paluma' was kept in a greenhouse with filtered air (activated carbon filters (VECO) for removal of gases, glass wool filters and paper for removal of coarse and thin particles). Visible foliar injuries ozone-induced were not observed in these saplings.

Gas exchange - Gas exchange analyzes were performed on young leaves ( $3^{\text {rd }}$ node from the apex, the first to present fully expanded leaves) and mature leaves ( $4^{\text {th }}$ node from the base, without signs of senescence) of saplings exposed to natural conditions. The measures of assimilation of $\mathrm{CO}_{2}$ under photosynthetically active

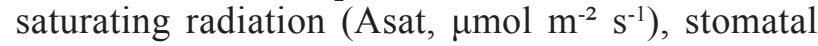
conductance (gs, $\mathrm{mol} \mathrm{m}^{-2} \mathrm{~s}^{-1}$ ), transpiration (E, mmol $\left.\mathrm{m}^{-2} \mathrm{~s}^{-1}\right)$ and intercellular $\mathrm{CO}_{2}$ concentration $(\mathrm{Ci}, \mu \mathrm{mol}$ $\mathrm{mol}^{-1}$ ) were performed using a portable infrared gas 
analyzer (LCPro +, ADC $\left.{ }^{\circ}, \mathrm{UK}\right)$. The gas exchanges were determined between 9:00 and 11:00 a.m., under ambient $\mathrm{CO}_{2}$ concentration and saturating photon flux density $\left(800 \mu \mathrm{mol} \mathrm{m}^{-2} \mathrm{~s}^{-1}\right)$. Water use efficiency (WUE, $\left.\mu \mathrm{mol} \mathrm{CO}\left(\mathrm{mmol} \mathrm{H}_{2} \mathrm{O}\right)^{-1}\right)$, was calculated with Asat and $\mathrm{E}$ results. During the experiment, 44 days of gas exchanges analysis $(\mathrm{n}=$ six plants) were performed with intervals of at least one week.

Statistical analysis - Results of gas exchange were tested for normality (Kolgomorov-Smirnov test) and homoscedasticity, after which a descriptive statistical analysis was performed. The Pearson correlation coefficient was calculated between carbon assimilation and stomatal conductance. The values of Asat, gs, E, Ci and WUE obtained at the beginning and at the end of the exposure period were used to calculate the percentage of relative variation: [(final value - initial value) / initial value] $* 100$.

The relationships between biotic and abiotic variables were evaluated using multivariate principal component analysis (PCA). Previous analyzes were made to choose the data to be used. The chosen data were then transformed into a correlation matrix, from which the PCA was generated. The biotic variables used were Asat, gs and $\mathrm{E}$. The abiotic variables were: mean temperature (Temp), mean relative humidity $(\mathrm{RH})$, mean VPD(VPD), cumulative rainfall (Rain), cumulative global solar radiation ( $\mathrm{Rad})$, accumulated $\mathrm{O}_{3}$ concentration from 7:00 am to 5:00 p.m. $\left(\mathrm{O}_{3}\right)$ and the length of the day (sumval), calculated as the distance from the days of analysis in relation to the winter solstice (June 21). The results of visible foliar injuries were correlated with the scores of the multivariate analysis axes.

The statistical programs used were SigmaStat 3.1 software (SYSTAT Software Inc. ${ }^{\circledR}$ ), for descriptive and correlation analysis; SPSS software (Statistical Package for the Social Sciences, SPSS ${ }^{\circledR}$ ), for principal component analyzes and the software PAST 1.3, for plotting principal component analysis.

\section{Results and Discussion}

Meteorological conditions and air quality - The temperature and relative humidity averages during the study period were $19.4{ }^{\circ} \mathrm{C}$ and $79.6 \%$, respectively. The lowest temperatures were recorded in Winter 2008 and Autumn 2008 and the highest in Summer 2008 (table 1). According to IAG/USP (2009), the study

Table 1. Daily means of temperature (Temp, $\left.{ }^{\circ} \mathrm{C}\right)$ and relative air humidity $(\mathrm{RH}, \%)$, rainfall (Rain, $\mathrm{mm}$ ) daily mean and hourly maximum of $\mathrm{O}_{3}, \mathrm{NO}_{2}$ and $\mathrm{NO}\left(\mu \mathrm{g} \mathrm{m}^{-3}\right)$ from April to June 2007 (Out/07), October to December 2007 (Pri/07), January to April 2008 (Ver/08), April to June 2008 (Oct/08), July to September 2008 (Inv/08) and October to December 2008 (Pri/08). nd: not determinated.

\begin{tabular}{|c|c|c|c|c|c|c|c|}
\hline & & Aut/07 & $\mathrm{Spr} / 07$ & Sum/08 & Aut $/ 08$ & Win/08 & $\mathrm{Spr} / 08$ \\
\hline \multirow{3}{*}{ Temp } & mean of means & 20.1 & 20.3 & 21.3 & 17.7 & 17.2 & 20.2 \\
\hline & mean of maximums & 26.2 & 25.9 & 26.7 & 23.3 & 24.0 & 26.2 \\
\hline & mean of minimum & 16.0 & 15.8 & 17.4 & 13.4 & 12.3 & 16.0 \\
\hline \multirow[t]{3}{*}{$\mathrm{RH}$} & mean of means & 79 & 81 & 82 & 80 & 76 & 80 \\
\hline & mean of maximums & 94 & 94 & 95 & 95 & 94 & 94 \\
\hline & mean of minimum & 53 & 59 & 60 & 57 & 49 & 56 \\
\hline Rain & cumulative volume & 119 & 369 & 483 & 185 & 130 & 258 \\
\hline \multirow{3}{*}{$\mathrm{O}_{3}$} & $24 \mathrm{~h}$ mean & 26 & 21 & 14 & 18 & 26 & 26 \\
\hline & maximum & 176 & 216 & 260 & 271 & 137 & 157 \\
\hline & $\mathrm{O}_{3}$ accumulated & 1942 & 1297 & 382 & 1744 & 1537 & 983 \\
\hline \multirow{2}{*}{$\mathrm{NO}_{2}$} & $24 \mathrm{~h}$ mean & 27 & 12 & 21 & 49 & 54 & nd \\
\hline & maximum & 135 & 95 & 115 & 401 & 377 & nd \\
\hline \multirow{2}{*}{$\mathrm{NO}$} & $24 \mathrm{~h}$ mean & 29 & 7 & 5 & 23 & 38 & nd \\
\hline & maximum & 445 & 186 & 96 & 407 & 339 & nd \\
\hline
\end{tabular}


period was warmer and drier (in reference to relative humidity) than the historical average of the city of São Paulo. The rainfall was similar to the average values for the city, except for the month of July 2008 that presented the lowest rainfall of all historical series.

During the experiment, there were few episodes of concentrations above $160 \mu \mathrm{m} \mathrm{m}^{-3}$, which is the national standard for this pollutant (CETESB 2009). The highest accumulated concentration of $\mathrm{O}_{3}$ was measured in Autumn 2007 (table 1). As increased solar radiation and temperature favored $\mathrm{O}_{3}$ formation, the higher $\mathrm{O}_{3}$ concentrations were expected to be recorded in the spring and summer seasons (September to March). However, it was the Summer 2008 that presented the lowest average concentration of $\mathrm{O}_{3}$ and accumulated $\mathrm{O}_{3}$ values much lower than expected. This probably occurred because in the period from December 2007 to March 2008 there was greater cloudiness and many days of precipitation in the city of São Paulo, resulting in $\mathrm{O}_{3}$ concentrations lower than those of previous years (CETESB 2009). Based on $\mathrm{O}_{3}$ concentrations, we may conclude that chronic exposures prevailed in the study period, with the predominance of low hourly concentrations and episodes of high concentrations restricted to a few days during the exposures (Bray et al. 2000).

The highest mean and maximum concentrations of $\mathrm{NO}_{2}$ were recorded in Winter 2008 and Autumn 2008 exposures. NO levels were high in these periods and also in Autumn 2007 (table 1). The occurrence of few episodes of high concentrations of $\mathrm{O}_{3}$ and high concentrations of $\mathrm{NO}_{2}$ and especially of $\mathrm{NO}$ was not expected, as the distance from sources emitting primary pollutants and the proximity to forest fragments favors the accumulation of $\mathrm{O}_{3}$ (EPA 2006).
However, as nitrogen is a macronutrient especially important to plants, its oxides become phytotoxic only when their concentration in the air is considerably high (Mansfield 2003). Wellburn (1993) states that a minimum concentration of about $1,080 \mu \mathrm{g} \mathrm{m}^{3}$ of $\mathrm{NO}_{2}$ and $720 \mu \mathrm{g} \mathrm{m}{ }^{3}$ of $\mathrm{NO}$ was required for 90 minutes for the inhibition of photosynthesis in Avena sativa and Medicago sativa. Since the most critical period in the present study was during the Autumn and Winter 2008 exposures, when mean $\mathrm{NO}_{2}$ and $\mathrm{NO}$ concentrations were $49 \mu \mathrm{g} \mathrm{m}^{-3}$ and $23 \mu \mathrm{g} \mathrm{m}^{-3}$ with a maximum hourly mean of $401 \mu \mathrm{g} \mathrm{m}^{-3}$ and $407 \mu \mathrm{g} \mathrm{m}^{-3}$, respectively, it may be concluded that the $\mathrm{NO}_{2}$ and $\mathrm{NO}$ concentrations recorded were not toxic to 'Paluma'.

Visible Foliar Injury - At all exposures the 'Paluma' leaves showed visible foliar injuries induced by $\mathrm{O}_{3}$ similar to those described in Furlan et al. (2007) and Pina \& Moraes (2007), showing that, although lower than in previous years, $\mathrm{O}_{3}$ concentrations during the study period were phytotoxic (table 2). The time before the initial manifestation of foliar injuries ranged from 9 days in Autumn 2007 to 40 days in Autumn 2008 (table 2). This variation was expected, since the appearance of injuries depends on the concentration of pollutant, which is modulated by the weather conditions that vary a lot as verified by Pina \& Moraes (2007). This occurs because environmental factors such as air humidity, temperature, DPV, soil moisture and wind speed in conjunction with biological factors such the stage of plant development, modulate stomatal conductance, determining the $\mathrm{O}_{3}$ dose that will be absorbed by leaf and thus the onset and severity of foliar injuries (Klumpp et al. 2006, Heath et al. 2009, CLRTAP 2015).

Table 2. Number of days until the onset of injuries, incidence, severity and Leaf Injury Index (\%) in saplings of Psidium guajava 'Paluma' in the periods of April to June 2007 (Autumn 2007), October to December 2007 (Spring 2007), January to April 2008 (Summer 2008), April to June 2008 (Autumn 2008), July to September 2008 (Winter 2008) and October to December 2008 (Spring 2008).

\begin{tabular}{lcccc}
\hline & $\begin{array}{c}\text { Onset of Injuries (days of } \\
\text { exposure) }\end{array}$ & $\begin{array}{c}\text { Incidence } \\
(\%)\end{array}$ & $\begin{array}{c}\text { Severity } \\
(\%)\end{array}$ & Leaf Injury Index (\%) \\
\hline Autumn/07 & 9 & 93 & 19 & 7.5 \\
Spring/07 & 33 & 100 & 20 & 8.7 \\
Summer/08 & 19 & 100 & 11 & 4.0 \\
Autumn/08 & 40 & 17 & 9 & 2.8 \\
Winter/08 & 33 & 100 & 13 & 5.0 \\
Spring/08 & 26 & $17^{*}$ & $10^{*}$ & $3.4 *$ \\
\hline
\end{tabular}

*determined one month before the end of the exposure, before abscission foliar 
At the end of the exposure periods practically all the plants presented injuries, except in Autumn 2008, when the incidence was $17 \%$. The highest values of severity and IIF occurred in the exposures of Autumn 2007 and Spring 2007 (table 2). In Spring 2008, the leaves that had injuries fell before the end of the exposure period, possibly due to the acceleration of cell senescence that is induced by $\mathrm{O}_{3}$ (Vollenweider et al. 2003). Leaf loss only in this exposure and not in those with the highest $\mathrm{O}_{3}$ accumulated concentration is also possibly due to the different absorbed concentrations of $\mathrm{O}_{3}$, which vary all the time, as demonstrated by Assis et al. (2015), which measured $\mathrm{O}_{3}$ stomatal flux in this species.

Gas exchanges - Gas exchanges means averages at the end of each exposure are shown in table 3. Carbon assimilation was highest in young 'Paluma' leaves at all exposures, except in Spring 2008. Stomatal conductance was highest in young leaves in Autumn 2007 and Autumn 2008 exposures and did not differ from the measure in the mature leaves in the other periods. Regarding transpiration, there were significant differences in Autumn 2007 and Winter 2008. Intercellular carbon concentration was lower in young leaves at all exposures except Spring 2008, with water use efficiency results being the opposite (higher in young leaves).

Although $\mathrm{O}_{3}$ exposure affected gas exchanges in leaves with different ages, mature leaves were more severely affected than the young ones (table 4). With regard to Asat, the final reduction occurred in young leaves only in Spring 2007, while in mature leaves reductions occurred in Autumn 2007, Spring 2007, Summer 2008 and Autumn 2008 (table 4). Stomatal conductance was reduced in young and mature leaves in Autumn 2007 and Autumn 2008 and remained similar to the initial gs at the end of other exposures for both ages leaves. Transpiration was significantly reduced in young and mature leaves in the same periods, Spring 2007, Summer 2008, Autumn 2008 and Spring 2008, but the reduction presented by mature leaves was higher (table 4). On the other hand, $\mathrm{C} i$ showed a significant increase at the end of some exposures, which occurred more frequently in mature leaves (three exposures) than in young leaves (one exposure) (table 4). The WUE, meanwhile, increased at the end of three exposures in the young leaves and was reduced in one, the opposite being verified in mature leaves (table 4). Work by Wei et al. (2004) and Zhang et al. (2010) also verified that mature leaves

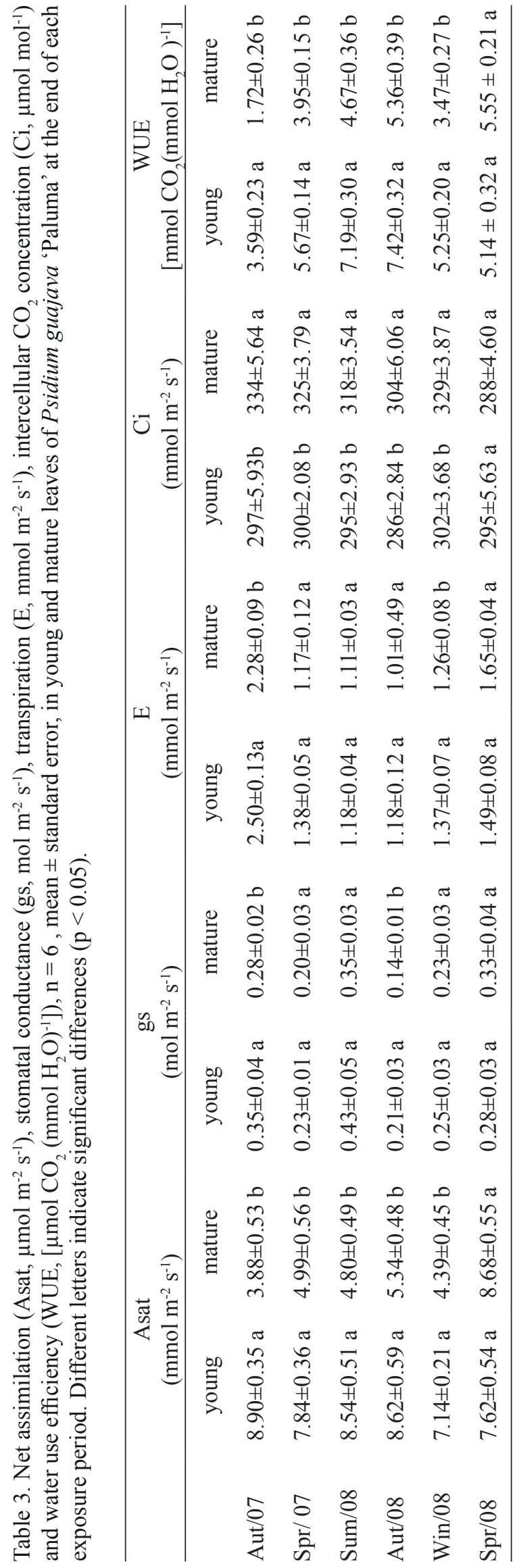




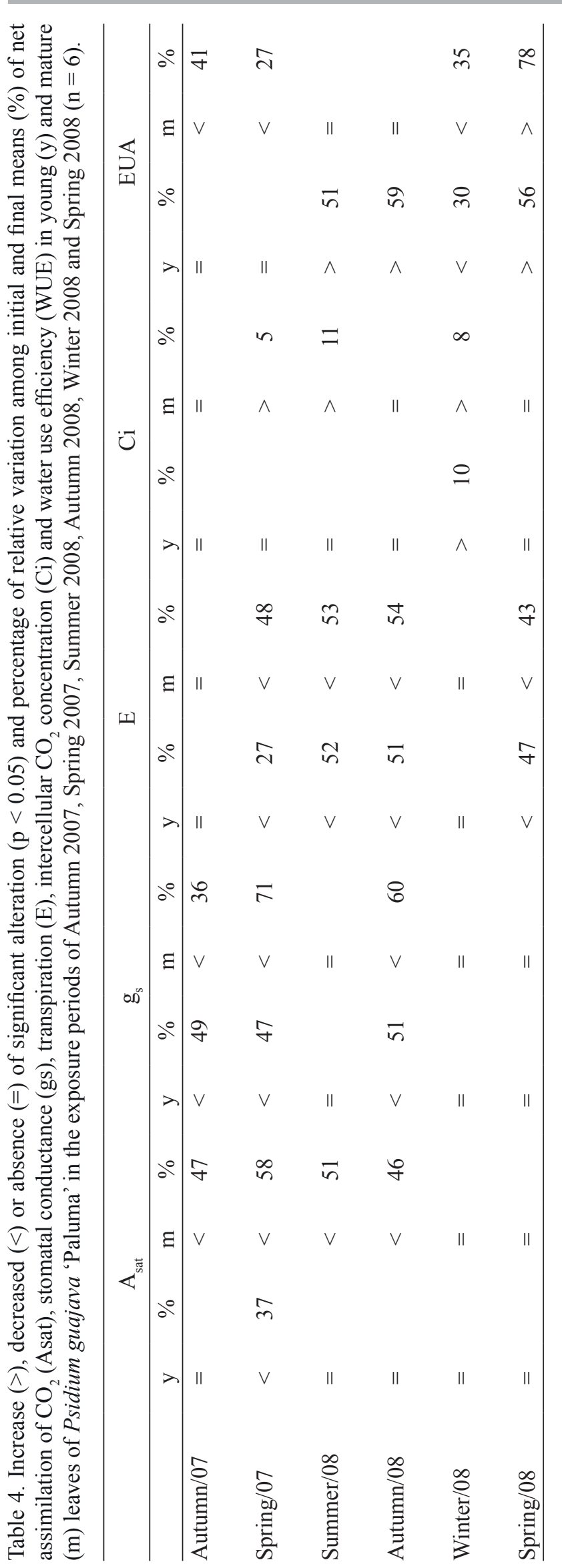

of tree species are more susceptible to $\mathrm{O}_{3}$ than more recently expanded leaves. According to Pell et al. (1994), by increasing the degradation of Rubisco and reducing its synthesis (loss of mRNA of Rubisco subunits), $\mathrm{O}_{3}$ would cause more disturbances in mature leaves, since these naturally have less protein synthesis. It is possible that Rubisco was affected in mature leaves, since there was an increase in $\mathrm{Ci}$. Thus, the decrease in stomatal conductance would not be the main cause of reduction in Asat, but a consequence of the increase of Ci. However, even though it is an indirect effect of $\mathrm{O}_{3}$-induced stress, the reduction of gs also contributes to limit Asat. Notwithstanding, other factors, such as ultraviolet radiation, are also capable of acting on Rubisco (Galmés et al. 2013).

Asat and gs presented a positive correlation (lower in Winter $2008 \mathrm{r}=0.56$, higher in Autumn $2007 \mathrm{r}=0.78$ ) in both young and mature leaves of 'Paluma', indicating that there was no desacoupling between these processes and, therefore, there was no damage to the stomatal control (Paoletti \& Grulke 2005). The WUE decrease in mature leaves shows that although plants maintained the control of the stomatal movements, the decrease of carbon assimilation make the plants more susceptible to stress.

Alterations in gas exchanges due to $\mathrm{O}_{3}$ exposure are often verified and, according to Heath et al. (2009), Asat is one of the first targets of $\mathrm{O}_{3}$-induced stress and is often accompanied by the reduction of gs (Witting et al. 2007, Kitao et al. 2009). In general, it is assumed that stomatal aperture is strongly accompanied by photosynthesis and is governed by Ci (Grulke et al. 2007). Guidi et al. (2001), in an experiment with Populus $x$ euramericana, verified that $\mathrm{Ci}$ did not change, in contrast to photosynthesis and conductance that showed a significant reduction after exposure to ozone. Based on these results, the authors concluded that the reduction in photosynthetic rate was not only due to the reduction in gs, but also due to a lower assimilation capacity of the mesophyll cells, since Ci did not vary. In this sense, Kitao et al. (2009) concluded that the reduction in Asat observed in adults of Fagus sylvatica after chronic exposure to $\mathrm{O}_{3}$ was mainly due to a stomatal limitation, since there was a reduction in $\mathrm{Ci}$.

Analysis of biotic and abiotic variables - The analysis performed with gas exchange results of young leaves of 'Paluma' synthesized $61 \%$ of the total variability of data in its two first ordering axes (figure 1 and table 5), while the PCA analysis carried out with data of mature 


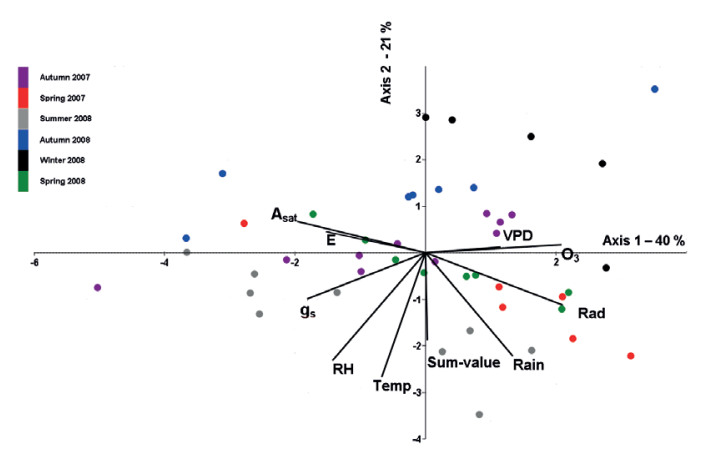

Figure 1. Principal component analysis of gas exchange and environmental variables in young leaves. Abbreviation: Asat: net assimilation of $\mathrm{CO}_{2}$; gs: stomatal conductance; E: transpiration; Sum-value: day length; $\mathrm{O}_{3}$ : accumulated concentration of $\mathrm{O}_{3}$; Temp: mean temperature; $\mathrm{RH}$ : mean relative humidity; VPD: vapor pressure deficit; Rain: accumulated rainfall; Rad: accumulated global solar radiation. Exposure periods: April to June 2007 (Autumn 2007), October to December 2007 (Spring 2007), January to April 2008 (Summer 2008), April to June 2008 (Autumn 2008), July to September 2008 (Winter 2008) and October to December 2008 (Spring 2008).

leaves summarized $55 \%$ of the total variability (figure 2 and table 6 ). In both PCA the variables that presented the highest correlation with axis 1 were: Asat $(r=-0.82$ and $\mathrm{r}=0.77$ in young and mature leaves, respectively), conductance $(\mathrm{r}=-0.74$ and $\mathrm{r}=0,62)$, transpiration $(\mathrm{r}$ $=-0.62$ and $\mathrm{r}=0.61), \mathrm{O}_{3}$ concentration $(\mathrm{r}=0.85$ and $\mathrm{r}$ $=-0.89)$ and radiation $(r=0.86$ and $r=-0.79)$ (tables 5 and 6). However, it is verified in PCA of mature leaves that the influence of VPD and day length (sum-value) are smaller than in PCA of young leaves.

A strong antagonism between $\mathrm{O}_{3}$ and the gas exchanges is observed on axis 1, indicating that
$\mathrm{O}_{3}$ accumulated exposure influenced the decrease of carbon assimilation, stomatal conductance and transpiration (figures 1 and 2). This opposition is most evident in mature leaves. It is concluded that, although there may be some effect of aging on results of mature leaves, this effect was intensified by $\mathrm{O}_{3}$ exposure.

The global radiation was also correlated with axis 1 and showed strong association with $\mathrm{O}_{3}$ and strong antagonism with Asat, gs and E (figures 1 and 2). This arrangement may show both the photochemical ozone formation process and the occurrence of photoinhibition. Bussotti et al. (2011) have shown that several parameters of chlorophyll a fluorescence are affected by exposure to $\mathrm{O}_{3}$ in temperate tree species. However, it should be noted that 'Paluma' is cultivated in the full sun conditions and that high levels of $\mathrm{O}_{3}$ and light energy generally occur simultaneously, since a high intensity of radiation is an essential condition for the formation of ozone in the troposphere. Thus, it is possible that the opposition between gas exchanges and radiation and $\mathrm{O}_{3}$ is more associated with the co-occurrence of the latter than with photoinhibition. Future studies with chlorophyll fluorescence could further investigate this relation. The main variables associated to axis 2 in both PCA were relative humidity $(r=-0.69$ and $r=-0.76$ in young and mature leaves, respectively), temperature $(\mathrm{r}=-0.79$ and $\mathrm{r}=-0.50)$ and precipitation $(\mathrm{r}=-0.66$ and $r=-0.75$ ). In the PCA of young leaves, in addition to the variables described above, it is observed that the sum-value (length of the day) also correlated with axis $2(r=-0.56)$ (table 5). The arrangement of the variables temperature and relative humidity on axis

Table 5. Pearson correlation coefficient of the variables related to the young leaves of Psidium guajava 'Paluma' with the main components and percentage of variability explained by the axes $(\%)(n=45)$.

\begin{tabular}{ccccc}
\hline Variables & \multirow{2}{*}{ Abbreviations } & \multicolumn{3}{c}{ Principal components } \\
\cline { 3 - 5 } & & -0.82 & 0.20 & 3 \\
\hline Carbon assimilation & $\mathrm{A}_{\text {sat }}$ & -0.74 & -0.29 & -0.18 \\
Stomatal conductance & $\mathrm{g}_{\mathrm{s}}$ & -0.62 & 0.13 & -0.27 \\
Transpiration & $\mathrm{E}$ & 0.01 & -0.56 & -0.33 \\
Daylenght & sum-value & 0.85 & 0.05 & 0.16 \\
Ozone & $\mathrm{O}_{3}$ & -0.27 & -0.79 & -0.20 \\
Temperature & $\mathrm{Temp}$ & -0.58 & -0.69 & -0.46 \\
Relative humidity & $\mathrm{RH}$ & 0.47 & 0.04 & 0.25 \\
Vapor pression deficit & $\mathrm{VPD}$ & 0.54 & -0.66 & -0.81 \\
Rainfall & $\mathrm{Rain}$ & 0.86 & -0.33 & 0.11 \\
Global radiation & $\mathrm{Rad}$ & $40 \%$ & $21 \%$ & -0.05 \\
\hline Explained variance & & & & $12 \%$ \\
\hline
\end{tabular}




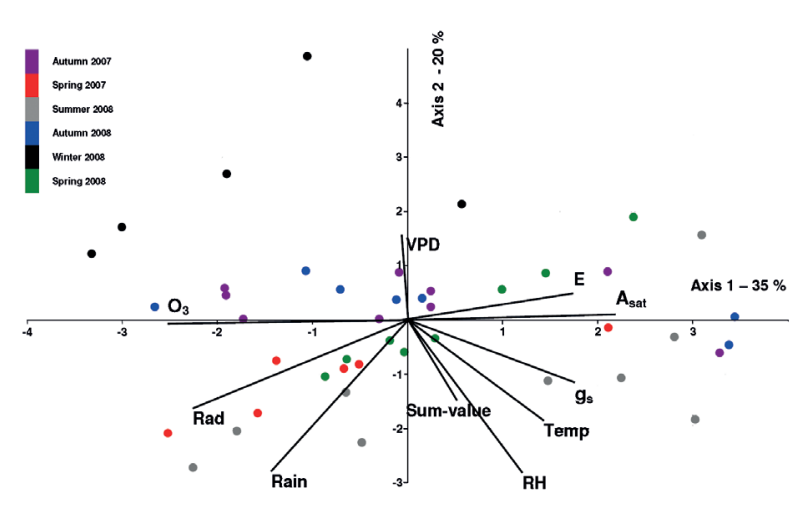

Figure 2. Principal component analysis of gas exchange and environmental variables in mature leaves. Abbreviation: Asat: net assimilation of $\mathrm{CO}_{2}$; gs: stomatal conductance; E: transpiration; Sum-value: day length; $\mathrm{O}_{3}$ : accumulated concentration of $\mathrm{O}_{3}$; Temp: mean temperature; $\mathrm{RH}$ : mean relative humidity; VPD: vapor pressure deficit; Rain: accumulated rainfall; Rad: accumulated global solar radiation. Exposure periods: April to June 2007 (Autumn 2007), October to December 2007 (Spring 2007), January to April 2008 (Summer 2008), April to June 2008 (Autumn 2008), July to September 2008 (Winter 2008) and October to December 2008 (Spring 2008).

2 of both graphs indicates the existence of a direct relationship between them (figures 1 and 2). It is also observed that this association is complemented by the sum-value variable, which would be reflecting the higher temperatures and humidity normally recorded in summer and spring seasons that present the largest day length (figure 1). A particular feature of PCA of mature leaves is the association of the temperature variable with both axis 2 and axis $1(\mathrm{r}=0.50)$, establishing, in the latter case, a direct relation with gas exchanges (figure 2) and evidencing the influence of the temperature on the gas exchanges of the mature leaves, whereas in the young leaves the effect of the temperature would be smaller. The variable VPD correlated with axis 3 in the two analyzes, and in PCA of mature leaves it appears in a position opposite to sum-value, indicating an indirect relation (figure 2).

In the PCA of young leaves, the points referring to results obtained in Spring 2007 and Spring 2008 were those that presented the most similar spatial distribution, following the axis formed by the vectors of Asat and radiation. The distribution of Summer 2008 points is more dispersed than those of spring and is more distant from the Asat-radiation axis, evidencing the influence of rainfall, temperature and relative humidity on its positioning. The results of winter are more grouped and opposed to these three vectors. The results of the autumn exposure are the most dispersed, reflecting the frequent meteorological oscillations in this season. The main characteristic of the PCA of mature leaves is the greater dispersion of the results for all the exposures.

The Pearson correlation coefficients between the axis 1 scores, resulting from the PCA of the mature leaves, and the parameters of leaf symptoms induced by $\mathrm{O}_{3}$ were calculated. Correlation resulted in a coefficient of -0.61 with incidence data, -0.64 with severity data and -0.58 with leaf injury index $(p<0.001)$. The correlation between axis 2 scores and injury data was not significant. The correlation with axis 1 indicated that the development of visible foliar injuries in 'Paluma', besides being directly related to greater exposure to $\mathrm{O}_{3}$, is related to a lower assimilation capacity. Chronic exposures to $\mathrm{O}_{3}$, such

Table 6. Correlation coefficient of the variables related to the mature leaves of Psidium guajava 'Paluma' with the main components and percentage of variability explained by the axes $(\%)(n=45)$.

\begin{tabular}{lcccc}
\hline \multirow{2}{*}{ Variables } & \multirow{2}{*}{ Abbreviations } & \multicolumn{3}{c}{ Principal components } \\
\cline { 3 - 5 } & & 1 & 2 & 3 \\
\hline Carbon assimilation & $\mathrm{A}_{\text {sat }}$ & 0.77 & 0.03 & 0.17 \\
Stomatal conductance & $\mathrm{g}_{\mathrm{s}}$ & 0.62 & -0.30 & -0.03 \\
Transpiration & $\mathrm{E}$ & 0.61 & 0.13 & -0.12 \\
Daylenght & sum-value & 0.18 & -0.40 & 0.69 \\
Ozone & $\mathrm{O}_{3}$ & -0.89 & -0.02 & -0.05 \\
Temperature & $\mathrm{Temp}$ & 0.50 & -0.50 & 0.30 \\
Relative humidity & $\mathrm{RH}$ & 0.42 & -0.76 & -0.36 \\
Vapor pression deficit & $\mathrm{VPD}$ & -0.02 & 0.42 & 0.80 \\
Rainfall & $\mathrm{Rain}$ & -0.51 & -0.75 & 0.16 \\
Global radiation & $\mathrm{Rad}$ & -0.79 & -0.44 & 0.14 \\
\hline Explained variance & & $35 \%$ & $20 \%$ & $14 \%$ \\
\hline
\end{tabular}


as observed during the study period, initially affect the metabolic processes, such as photosynthesis, not causing or causing later the manifestation of visible foliar injuries (Bray et al. 2000, EPA 2006, Gielen et al. 2007, Overmyer et al. 2009). The reduced assimilation of carbon results in lower production capacity of antioxidants for the processes of defense and repair of damages, therefore, the increase of injuries. This process is related to the acceleration of leaf senescence, which results from the anticipation of the beginning of senescence process due to oxidative stress induced by $\mathrm{O}_{3}$ byproducts (Alves et al. 2016), which may have occurred in Spring 2007, when occur leaf abscission 30 days before the exposure end. The results showed that $\mathrm{O}_{3}$ has a more severe impact on mature leaves and the relative importance of meteorological variables differs slightly between young and mature leaves, with VPD, $\mathrm{O}_{3}$ concentration and radiation being the main variables associated with the reduction of gas exchange in young leaves. In mature leaves the influence of VPD is lower, but the temperature is higher. On the other hand, the opposition between assimilation and $\mathrm{O}_{3}$ is more evident in the mature leaves, indicating their greater sensitivity to the pollutant.

\section{Acknowledgements}

The authors are grateful to Institute of Astronomy, Geophysics and Atmospheric Sciences of the University of São Paulo for the provision of meteorological data and to FAPESP for financial support (Processo 05/51169-9 and Processo 06/1535).

\section{Literature cited}

Alves, E.S., Moura, B.B., Pedroso, A.N.V., Tresmondi, F. \& Rodrigues, S.M. 2016. Cellular markers indicative of ozone stress on bioindicator plants growing in a tropical environment. Ecological Indicators 67: 417-424.

Assis, P.I.L.S., Alonso, R., Meirelles, S.T., Moraes, R.M. 2015. $\mathrm{DO}_{3} \mathrm{SE}$ model applicability and $\mathrm{O}_{3}$ flux performance compared to AOT40 for an $\mathrm{O}_{3}$-sensitive tropical tree species (Psidium guajava Paluma). Environmental Science and Pollution Research International 22: 10873-10881.

Bray, E.A., Bailey-Senes, J. \& Weretilny, K.E. 2000. Responses in abiotic stress. In: B.B. Buchanan, W. Gruissen \& R.L. Jones (eds.). Biochemistry and molecular biology of plants. American Society of Plant Physiologist, New York, pp. 1158-1203.
Bussotti, F., Desotgiua, R., Cascioa, C., Pollastrini, M., Gravanoa, E., Gerosa, G., Marzuoli, R., Nali, C., Lorenzini, G., Salvatori, E., Manes, F., Schaub, M. \& Strasser, R. 2011. Ozone stress in woody plants assessed with chlorophyll a fluorescence. A critical reassessment of existing data. Environmental and Experimental Botany 73: 19-30.

Cassimiro, J.C. \& Moraes, R.M. 2016. Responses of a tropical tree species to ozone: visible leaf injury, growth, and lipid peroxidation. Environmental Science and Pollution Research 23: 8085-8090.

CLRTAP Convention on long range transboundary air pollution. 2015. Mapping Critical Levels for Vegetation, Chapter III of Manual on Methodologies and Criteria for Modelling and Mapping Critical Loads and Levels and Air Pollution Effects, Risks and Trends. Available in www.icpmapping.org (access in 11-03-2016).

CETESB - Companhia Ambiental do Estado de São Paulo. 2009. Relatório de Qualidade do Ar no Estado de São Paulo 2008. Governo de Estado de São Paulo, SP. Available in http://www.cetesb.sp.gov.br/Ar/ publicacoes.asp (access in 21-04-2016).

De Temmerman, L., Nigel, J., Bell, B., Garrec, J.P., Klumpp, A., Krause, G.H.M. \& Tonneijick, A.E.G. 2004. Biomonitoring of air pollutants with plants considerations for the future. In: A. Klumpp, W. Ansel \& G. Klumpp (eds.). Urban air pollution, bioindication and environmental awareness. Curvillier Verlag, Göttingen, pp. 337-373.

EPA - Environmental Protection Agency. 2006. Air Quality Criteria for Ozone and Related Photochemical Oxidants (2006 Final). U.S. Environmental Protection Agency, Washington, DC, EPA/600/R-05/004aF-cF.

Furlan, C.M., Moraes, R.M., Bulbovas, P., Domingos, M., Salatino, A. \& Sanz, M.J. 2007. Psidum guajava 'Paluma' (the guava plant) as new bio-indicator of ozone in the tropics. Environmental Pollution 147: 361-365.

Galmés, J., Aranjuelo, I., Medrano, H. \& Flexas, J. 2013. Variation in Rubisco content and activity under variable climatic factors. Photosynthesis Research 117: 73-90

Gielen, B., Löw, M., Deckmyn, G., Metzger, U., Franck, F., Heerdt, C., Maytssek, R., Valcke, R. \& Ceulemans, R. 2007. Chronic ozone exposure affects leaf senescence of adult beech trees: a chlorophyll fluorescence approach. Journal of Experimental Botany 58: 785-795.

Grulke, N.E., Neufeld, H.S., Davison, A.W., Roberts, M. \& Chapelka, A.H. 2007. Stomatal behavior of ozonesensitive and -insensitive coneflowers (Rudbeckia laciniata var. digitata) in Great Smoky Mountains Park. New Phytologist 173: 100-109.

Guidi, L., Nali, C., Lorenzini, G., Filippi, F. \& Soldatini, G.F. 2001. Effect of chronic ozone fumigation on the photosynthetic process of poplar clones showing different sensitivity. Environmental Pollution 113: $245-254$. 
Heath, R.L., Lefohn, A.S. \& Musselman, R.C. 2009. Temporal processes that contribute to nonlinearity in vegetation responses to ozone exposure and dose. Atmospheric Environment 43: 2919-2928.

IAG/USP - Instituto de Astronomia, Geofísica e Ciências Atmosféricas da Universidade de São Paulo. 2009. Boletim Climatológico Anual da Estação Meteorológica do IAG/USP -2008. Universidade de São Paulo, São Paulo. Available in http://www.estacao.iag.usp.br/ boletim.php (access in 15-03-2016).

Kitao, M., Löw, M., Heerdt, C., Grams, T.E.E., Häberle, K-H. \& Matyssek, R. 2009. Effects of chronic elevated ozone exposure on gas exchange responses of adult beech trees (Fagus sylvatica) as related to the within-canopy light gradiente. Environmental Pollution 157: 537-544.

Klumpp, A., Ansel, W., Klumpp, G., Vergne, P., Sifakis, N., Sanz, M.J., Rasmussen, S., Ro-Poulsen, H., Ribas, A., Peñuelas, J., Kambezidis, H., He, S., Garrec, J.P. \& Calatayud, V. 2006. Ozone pollution and ozone biomonitoring in European cities. Part II. Ozoneinduced plant injury and its relationship with descriptors of ozone pollution. Atmospheric Environment 40: 7437-7448.

Mansfield, T.A. 2003. Nitrogen oxides: old problems and new challenges. In: J.N.B. Bell \& M. Treshow (eds.). Air Pollution and Plant Life. John Wiley \& Sons Ltda, West Sussex, pp. 119-134.

Overmyer, K., Wrzaczek, M. \& Kangasjärvi, J. 2009. Reactive oxygen species in ozone toxicity. In: L.A. Río \& A. Puppo (eds.). Reactive Oxygen Species in Plant Signaling. Springer-Verlag, Berlim, pp.191-208.

Paoletti, E. \& Grulke, N.E. 2005. Does living in elevated $\mathrm{CO}_{2}$ ameliorate tree response to ozone? A review on stomatal responses. Environmental Pollution 137: 483-493.
Pell, E.J., Schlagnhaufer, D. \& Arteca, R. 1997. Ozoneinduced oxidative stress: mechanisms of action and reaction. Physiologia Plantarum 100: 264-273.

Pina, J.M. \& Moraes, R.M. 2007. Ozone-induced foliar injury in saplings of Psidium guajava 'Paluma' in São Paulo, Brazil. Chemosphere 66: 1310-1314.

Sandré, A., Pina, J.M., Moraes, R.M. \& Furlan, C.M. 2014. Anthocyanins and tannins: is the urban air pollution an elicitor factor? Revista Brasileira de Botânica 37: 9-18.

Vingarzan, R. 2004. A review of surface ozone background levels and trends. Atmospheric Environment 38: 3431-3442.

Vollenweider, P., Ottiger, M., Günthardt-Goerg, M.S. 2003. Validation of leaf ozone symptoms in natural vegetation using microscopical methods. Environmental Pollution 124: 101-118.

Wei, C., Skelly, J.M., Pennypacker, S.P., Ferdinand, J.A., Savage, J.E., Stevenson, R.E. \& Davis, D.D. 2004. Influence of light fleck and low light on foliar injury and physiological responses of two hybrid poplar clones to ozone. Environmental Pollution 130: 215-227.

Wellburn, A.R. 1993. Why are atmospheric oxides of nitrogen usually phytotoxic and not alternative fertilizers? New Phytologist 115: 395-429.

Witting, V.E., Ainsworth, E.A. \& Long, S.P. 2007. To what extent do current and projected increases in surface ozone affect photosynthesis and stomatal conductance of trees? A meta-analytic review of the last 3 decades of experiments. Plant, Cell and Environment 30: 1150-1162.

Zhang, J., Schaub, M., Ferdinand, J.A., Skelly, J.M., Steiner, K.C. \& Savage, J.E. 2010. Leaf age affects the responses of foliar injury and gas exchange to tropospheric ozone in Prunus serotina seedlings. Environmental Pollution 158: 2627-2634. 